Rev. Józef Budniak

University of Silesia in Katowice, Department of Theology

\title{
The Reception of the Decree on Ecumenism Unitatis Redintegratio in Cieszyn Silesia
}

There are certain places throughout the world where ecumenical movements are born and have arisen out of the very essence the sociocultural realities of these places. The Cieszyn region of Silesia is such a place. In Cieszyn, different nationalities, cultures, and religions converge because the region both literally and symbolically contains many borders. Many Christian denominations peacefully coexist within Cieszyn, which is home to the largest community of Lutherans in Poland. The ecumenical movement within Cieszyn arose as a necessary and inevitable consequence of the coexistence of these Churches. For this reason, the Cieszyn region of Silesia is a perfect example of contemporary trends that are occurring within the ecumenical movement.

Ecumenism in the Cieszyn region of Silesia has a very long and rich history that began more than five centuries ago, meaning long before the Second Vatican Council issued the Decree on Ecumenism Unitatis Redintegratio. Two Christian denominations-Roman Catholic and Lutheran-have coexisted in Cieszyn Silesia and, therefore, have become a symbol of an ecumenism based on faith and tolerance as well as survival and respect. Each of these represent the modern understanding of ecumenism today.

The ecumenical movement can serve as a solid foundation that strengthens a sense of unity within local communities that share the same cultural and Christian roots so that these communities can achieve a common goal: to build a civilization of love, peace, and justice.

Based on the examples of ecumenical relationships at work provided in this article, it is possible to say that the wise of "today" look back on "yesterday" in order to build a better "tomorrow."Therefore, it is safe to assert that an ecumenism well-lived in the present that is also firmly rooted in history is a source of hope for the future of Christian Churches and communities. 
When presenting how the multi-denominational population of Cieszyn Silesia received the Decree on Ecumenism Unitatis Redintegratio, a statement made by one of the most eminent Polish ecumenists, Father Prof. Wacław Hryniewicz, comes to mind: "An authentic reception can be achieved only when the partners differ from each other, because diversity enables the true relationship between giving and taking."

Key words: ecumenism, Cieszyn Silesia, ecumenism, Second Vatican Council, history, reception.

\section{Introduction}

In some places, the ecumenical movement arose and has grown out of the very essence of their sociocultural reality, which itself is the result of given location's historical experience, specific cultural heritage, and contemporary religious changes. The Cieszyn region of Silesia ${ }^{1}$ is one such place. Cieszyn includes both literally and figuratively many borders where various nationalities, cultures, and Christian denominations converge. One of the most important features of this region is the fact that the Christian denominations peacefully coexist. While the number of Evangelicals totals 80,000 in Poland, Cieszyn is home to Poland's largest population of Lutherans (about 50,000). The ecumenical movement that arose and has developed within Cieszyn was a necessary and inevitable consequence of the coexistence of the Christian denominations that coexist there. Given the peaceful coexistence of these denominations, Cieszyn Silesia serves as a perfect example of contemporary trends within the ecumenical movement.

The Cieszyn region of Silesia, but particularly the town of Cieszyn itself, which was the capital of the Duchy of Cieszyn from 1290 to 1918, has a certain genius loci, meaning prevailing atmosphere that was influenced in a particular way by the Reformation that began in 1517 . Genius loci applies to a place and is thought to be an important element in the search of the existential space of a people who belong to different Christian and religious communities. Both history and the present day provide much evidence of how it is important to understand the spirit of a place well. They also inspire us to engage in ecumenical activities on three planes - spiritual, cultural, and academic. A great

1 A. Heinrich, Versuch über die Geschichte des Herzogthums Teschen von den ältesten bis auf gegenwärtige Zeiten, Teschen 1818; F. Slama, Dějiny Těšinska, Prag, 1889, passim; G. Biermann, Geschichte des Herzogthums Teschen, Teschen 1894, passim; F.Popiołek, Dzieje Ślaska austriackiego zilustracjami, Cieszyn1913, passim; I. Panic, "Ziemia Cieszynska w czasach piastowskich (X-XVI wiek)," in: Śląsk Cieszynski. Zarys dziejów, Cieszyn 1998, pgs. 25-43. 
example of this activity is the September Bible, which Martin Luther translated from the Vulgate into German and published in Wittenberg in September 1522, a copy of which can be found in Cieszyn. Although 3,000 first-edition copies of the September Bible were printed, which was a large quantity for that time, only a few copies have survived and are being housed in different Polish collections. Apart from the copy at the Cieszyn Library, only three other copies exist: two copies are respectively housed in the Nicolaus Copernicus University Library and Municipal Library in Torun, and one copy is housed in the collections of the Wrocław University Library.

\section{Methodological Approach}

Since the Second Vatican Council, ecumenism has been an integral and permanent part of the Roman Catholic Church's activities. The Council expressed the Church's desire to engage in ecumenism in order to bring about the unity of Christians. In the Decree on Ecumenism Unitatis Redintegratio, the Church encourages "all the Catholic faithful to recognize the signs of the times and to take an active and intelligent part in the work of ecumenism" (4). ${ }^{2}$ Since the beginning of John XXII's pontificate, he and the popes who followed him have made ecumenism a priority. In his encyclical Ut Unum Sint, John Paul II says that "[t]he Catholic Church embraces with hope the commitment to ecumenism as a duty of the Christian conscience enlightened by faith and guided by love" (8). ${ }^{3}$ In this way, the Church's aim is to pursue the unity of Christians.

In his essays on the Eucharist, the contemporary Orthodox theologian, Alexander Schmemann, said that "in the heart of Christianity there is the memory of one Man, of one moment, of one night when the words 'This do in remembrance of me' were spoken in the darkness." 4 In other words, at the heart of Christianity lies the memory of Holy Thursday, of the Upper Room when Jesus left us his testament, saying, "Holy Father, keep them in thy name which thou hast given me, that they may be one, even as we are one" before he commanded: "Do this in remembrance of me" (Jn 17:11). Unity, therefore, is both a gift from Jesus and a task for all Christians. Accordingly, Jesus commands ecumenism, and Christians must fulfill this command because it is

2 Second Vatican Council, Decree on Ecumenism Unitatis Redintegratio. Abbreviated hereafter as UR. John Paul II, Encyclical Ut unum sint. Abbreviated hereafter as UUS. 
"the way of the Church" and "the duty of the Christian conscience" (UR 7, 8).

In order to better understand how receptive the people of the Cieszyn region of Silesia were to the Decree on Ecumenism Unitatis Redintegratio, it is necessary to first define the term ecumenism. Unitatis Redintegratio describes ecumenism as a process toward unity that the Holy Spirit inspires. Jesus expressed this unity in his prayer as High Priest, "That they may all be one [...]" (cf. Jn 17:21). According to the Second Vatican Council, the expression "ecumenical movement" indicates the "initiatives and activities planned and undertaken, according to the various needs of the Church and as opportunities offer, to promote Christian unity" (UR 4). Reception, which is an indigenous ecclesiastical phenomenon, is indispensable for ecumenism and unity. It is "an expression of spiritual exchange between individuals and entire communities." Reception takes place in Churches and Christian communities where people accept theological formulations, various traditions, and ecclesial structures in a great spirit of togetherness of faith. Ecumenical reception, which recognizes that other Churches have a right to their own identity, derives significant values from these denominations that enrich all Christians. The engagement that occurs between different denominations within the ecumenical movement is "the first form of mutual reception and a silent acceptance of the ecclesiality of other communities." ${ }^{6}$ Reception, which involves recognizing the rights of other Churches, is the basis for rapprochement and ecumenical agreement between Christians on the path to unity. The aim of ecumenical reception is, therefore, to lead again "to the integration of many denominational traditions and take from them the essential and lasting values that can enrich all other Christians."

\section{Post-Conciliar Reception of the Decree Unitatis Redintegratio in Cieszyn Silesia}

Ecumenism in Cieszyn Silesia has a very long and rich history that began long before the Second Vatican Council issued the Decree on Ecumenism Unitatis Redintegratio on November 21, 1964. For those whose families have lived in Cieszyn for centuries, Cieszyn Silesia

$5 \quad$ Rev. Prof. Wacław Hryniewicz extensively discusses the issue of reception as an ecumenical task for Churches and Church communities. Cf. W. Hryniewicz, Hermeneutyka $w$ dialogu, Opole 1998, pgs. 125-192.

Ibid. pg. 152.

Ibid. pg. 159. 
has always been a center for two denominations: Roman Catholic and Lutheran. The coexistence of these two groups has become a symbol of ecumenical life, meaning faith and tolerance, survival and respect. Both Roman Catholics and Lutherans in Cieszyn have also retained their own traditions and culture. Today all of these factors shape the modern image of ecumenism in this region where Roman Catholics and Lutherans marry each, and the faithful of both denominations also work and participate in religious, cultural, social, and political life together. Peaceful coexistence among the various confessions began almost five centuries ago when Protestant influences reached Cieszyn Silesia. Thanks to the mutual kindness and understanding that existed among the inhabitants of the region, especially during the $19^{\text {th }}$ century, an economic boom in education occurred, and children of different denominations started to attend elementary and high schools run by the Catholic and Evangelical Churches. Everyone, regardless the confession, was able to find a place in Cieszyn.

\section{Spiritual Ecumenism}

Numerous spiritual, doctrinal, practical, and folk ecumenical initiatives take place in Cieszyn Silesia.

According to the Decree on Ecumenism, the soul of the ecumenical movement is made up of the transformation of heart and sanctity of life connected with prayers for the unity of Christians (cf. DE 8). As a form of spiritual ecumenism, ecumenical prayer is an effective means of asking for the grace of unity and a sign of the bond that connects the baptized according to Jesus' words: "For where two or three are gathered together in my name, there am I in the midst of them" (Mt 18:20). ${ }^{8}$ John Paul II stressed the importance of prayer for the unity of Christians in his encyclical Ut Unum Sint:

Along the ecumenical path to unity, pride of place certainly belongs to common prayer, the prayerful union of those who gather together around Christ himself. If Christians, despite their divisions, can grow ever more united in common prayer around Christ, they will grow in the awareness of how little divides them in comparison to what unites them. If they meet more often and more regularly before Christ in prayer, they will be able to gain the courage to face all the painful human reality of their divisions, and they will find themselves together once more in that community of the Church which Christ constantly builds up in the Holy Spirit, in spite of all weaknesses and human limitations (22). 
In Cieszyn Silesia, in Poland, and in the entire Roman Catholic Church, ecumenical prayer began when the Church began to carry out the Second Vatican Council's ecumenical resolutions. The Week of Prayer for Christian Unity, which is celebrated from January 18-25 every year, plays a significant role in this effort. Not only Catholics, Lutherans, and Seventh-Day Adventists but also members of the Orthodox and Polish Catholic Churches participate in the ecumenical prayers that take place during this special week in Cieszyn Silesia. In many places in this region, especially where Evangelicals and Catholics live, ecumenical prayer services for the unity of Christians are celebrated every day. During these services, Roman Catholic and Evangelical clergy preach the word of God, and choir performances enrich the services. In fact, during one of the ecumenical services, Rev. Jan Gross, the Chairman of the Silesian Department of the Polish Ecumenical Council, said that it seems that "[w]e understand each other better, many prejudices have disappeared, and what once [seemed] impossible is now a reality" after so many years of praying together.

The International Day of the Bible is another occasion to celebrate biblical and ecumenical services in many towns and villages in the region of Cieszyn. The first celebration of this day began in 1998. In most places, services for the International Day of the Bible are preceded by lectures in biblical theology, and not only Catholics and Evangelicals but also Seventh-Day Adventists and members of Polish Catholic Church participate in this event. ${ }^{10}$ The Committee for Ecumenical Biblical Days organizes these meetings. This ecumenical cooperation focuses on making the Holy Bible more popular among young people through Bible competitions held at schools. ${ }^{11}$

Every year, as part of the Week of Prayer for Christian Unity, Catholic and Evangelical bishops take part in the Bible Reading Marathon in Bielsko-Biała's main library. During this event, representatives of different Christian denominations as well as the Jewish community read passages from Scripture. The diocesan radio station "Aniol Beskidów [Angel of the Beskid Mountains]" broadcasts the Bible Reading Marathon.

$9 \quad$ J. Budniak, Ekumenizm jutra na przykładzie Ślaska Cieszynskiego, Katowice 2002, pg. 127.

10 J. Budniak, "Ekumenizm na Śląsku Cieszynskim na przełomie wieków," in: Pojednajcie się..., pg. 74

11 J. Budniak, Ekumenizm jutra na przykładzie Ślaska Cieszynskiego. Studium historyczno-pastoralne, Katowice 2002, pg. 119. 
Since 1997, Roman Catholic and Evangelical Churches have organized the "Jonasz" Bible Competition under the auspices of Catholic and Evangelical bishops. Students from all kinds of schools can participate in the annual event. Several thousand primary and secondary school students from the Roman Catholic Diocese of Bielsko-Żywiec and the Evangelical Church of the Augsburg Confession's Dioceses of Cieszyn and Katowice, as well as young people from the Silesian Evangelical Church of the Augsburg Confession on the other side of the Olza River in the Czech Republic participate in this competition. Bogusław Czyż, the President of the Religious Education Society "Jonasz" from Skoczów and the Religious Education Department of the Bielsko-Żywiec curia have organized the event for the past 17 years. Czyż admitted that relations between the representatives of the different denominations have developed and improved because of this even: "The competition brings people together and not only lets them explore the Bible but also enables them to meet with one another. I am pleased with the fruitful results of this cooperation." 12

In 2008, the Evangelical Church of Augsburg Confession parish in Cieszyn celebrated the $300^{\text {th }}$ anniversary of its founding, which served as an occasion for a very festive ecumenical service. The service inaugurating the jubilee celebrations took place on October 5 in the Church of Jesus, and many of the clergy and faithful representing all Churches and Christian communities in Cieszyn Silesia attended. Bishop Tadeusz Rakoczy represented the Roman Catholic Church, and Polish President Lech Kaczyński and the Chairman of European Parliament Jerzy Buzek were also present.

The common prayer for freedom, which is the gift of God's love, must be based on four pillars: truth, justice, love, and freedom because "...true peace blossoms when hatred, resentment and envy are uprooted from the heart, when one says ' $n o$ ' to selfishness and to all that drives the human being to withdraw into himself and defend his own interests." ${ }^{13}$ Ecumenical services for freedom, which draw from the example of the interreligious prayer meetings that Pope John Paul II initiated and that were organized for the first time in Assisi in 1986, are another way in which the different communities exemplify their work towards unity.

12 From the author's the private archives. Catalog number JB/KBib/2014.

13 John Paul II, "Address to the Young People Taking Part in the International Meeting UNIV 2003," April 14, 2003, https://w2.vatican.va/content/john-paul-ii/ en/speeches/2003/april/documents/hf_jp-ii_spe_20030414_univ-2003.html (accessed 10.30.2019). 
The first international service that clergy from Poland and the Czech Republic attended took place in John the Baptist church in Brenna on March 18, 2002. Representatives of five Christian churches were present. Bishop Tadeusz Rakoczy of the Diocese of Bielsko-Żywiec presided over the communal prayer and Bishop Tadeusz Szurman of the Diocese of Katowice's Evangelical Church of the Augsburg Confession preached.

Because of his appreciation of the role and significance of ecumenical dialogue in the Cieszyn region of Silesia, Polish President Bronisław Komorowski visited Cieszyn to participate in an ecumenical prayer service for world peace on September 1, 2011. Catholic and Lutheran bishops also participated along with many of the Catholic and Lutheran faithful. Referring to the geographical location of Cieszyn, President Komorowski said that: "a voice from here, form the border of nations, languages, cultures, and religions proves that being different does not mean misfortune but the beauty and wealth of Poland and all of the world's nations." ${ }^{14}$ Bishop Tadeusz Rakoczy preached the sermon during the service. While addressing the congregation, the bishop asked everybody to pray every day for freedom in families, in Poland, and in the world. It was the second prayer service for freedom in the history of the diocese.

The next service for freedom took place in the oldest church in Poland-the Romanesque chapel in Cieszyn—on June 5, 2019. Three Christian groups participated in the ceremony: Roman Catholic, Orthodox, and Lutheran. During the service, the bishops made a joint appeal for freedom in the world.

\section{Academic Ecumenism}

In a way the history of academic ecumenism in Cieszyn Silesia begins with the International Ecumenical Congress held at the University of Silesia in Cieszyn from August 21-28, 1995. The phrase "Ora et labora: Renew us through prayer and work" was the primary inspiration of the lectures given by Roman Catholic, Orthodox and Lutheran academics. When welcoming the participants, Bishop Tadeusz Rakoczy expressed his own joy as well as the joy of the entire local Church, saying:

The $28^{\text {th }}$ International Ecumenical Congress is held here in Cieszyn,

Poland, on the piece of land where the holy commandment of Christian

$14 \quad$ J. Budniak, "Wkład społeczności lokalnej w proces pojednania chrześcijan," in: Człowiek dialogu, ed. Z Glaeser, Opole 2012, pg. 617. 
unity is fulfilled. The commandment is even more holy because it is not expressed as a direct order but through [Jesus'] prayer during [His] intimate conversation with the Father on the night before His death and in the face of the fulfillment of the entire Paschal Mystery. Christ entrusts this matter to us through the Holy Father with a zeal that is proper only to Him, the only Begotten Son of God. This sensitivity ignites Churches-communities of people who believe in Christ—even more and more. The Congress takes place on earth where the evangelic call for Christian unity responds to the everyday need of people who live here. ${ }^{15}$

A group of 340 people represented all of the Christian denominations from Europe, the United States, and Madagascar at the Congress. The importance of this event was emphasized by the presence of the following distinguished guests: Cardinal Henryk Gulbinowicz and the President of Poland Lech Wałęsa.

The Cieszyn Silesia calendar includes permanent ecumenical ceremonies that have religious and state dimensions. The fact that the prayer for Christian unity during the Jubilee Year (March 25, 2000) was recited during ecumenical services and academic sessions is highly symbolic. This event took place in two Polish towns - Białystok (Roman Catholic-Orthodox) and in Bielsko-Biała (Roman CatholicEvangelical). The ecumenical service in Bielsko-Biała was preceded by an academic session at the St. John Cantius Theological Institute. During this session, Bishop Tadeusz Rakoczy focused on the values by which the ecumenical process should be guided and embody: a daily life shaped by faith, prayer, a discernment of God's will expressed in the Holy Bible, repentance, and reconciliation. Bishop Tadeusz Rakoczy said that living the virtue of charity with one's fellow men leads to the unity of all people on the condition that people acknowledge and confess their sins against unity, change the way that they think and behave towards others, are ready to accept the logotype of Christ's Gospel, have hearts that are sensitive to the Word of God and, in the light of this Word, sensitive to others and their inner freedom. ${ }^{16}$

During the sermon that he delivered at ecumenical service that completed the conference, Archbishop Alfons Nossol asked two questions:

15 "The Ordinary Bishop of the Diocese of Bielsko-Żywiec Tadeusz Rakoczy's Address to the Participants of the International Ecumenical Congress," in: J. Budniak, XXVIII Międzynarodowy Kongres Ekumeniczny w Cieszynie. Ora et labora. Cieszyn-Bytom 1996, pgs. 33-36.

16 T.Rakoczy, "Słowo wygłoszone podczas nabożeństwa ekumenicznego w kościele pw. Najświętszego Serca Pana Jezusa w Bielsku-Białej, 25 marca 2000 roku," in: Pojednajcie się..., eds. J. Budniak, H. Rusek, Cieszyn 2000, pg. 224. 
What will united diversity look like in the future? And, when exactly will the hour of unity strike? Answering these questions, he recalled the great witness of the faith of John Paul II who apologized before the whole world on behalf of the daughters and sons of the Church bearing the name of Christians on the first Sunday of Lent-the Sunday of Forgiveness-in 2000. Continuing his idea, Archbishop Nossol said:

[T] he Pope embraced the legs of the Crucified, kissed them, and begged Him to forgive us the sins that we have committed that have led to division; for the grace to rid ourselves of any further willfulness that divides us and tears Christ's robe apart; and to fill our hearts with an ardent love of unity and of true reconciliation. When this elderly man with such a youthful heart and spirit embraced Christ's cross, I was reminded of Fr. Dr. Martin Luther's words: Crux probat optima... (The cross tests everything....). ${ }^{17}$

The Decree on Ecumenism Unitatis Redintegratio highlights that "it is necessary to come to know the spirit of the separated brothers" (9). Conferences and academic sessions serve this purpose and provide a context for ecumenical meetings. Dialogue makes mutual meetings and understanding possible. This form of ecumenism is included in all ecumenical conferences and academic sessions held both at the University of Silesia in Cieszyn and the St. John Cantius Theological Institute in Bielsko-Biała. ${ }^{18}$ The conferences have been held every year since 1999 when the University of Silesia's Department of Pedagogy in Cieszyn offered to students the opportunity to specialize in Catholic and Evangelical religious education in order to teach within both Catholic and Evangelical Churches. However, this specialization ceased to be offered at the University of Silesia in Cieszyn in 2007 because the Department of Theology at the University of Silesia in Katowice began to offer the same specialization in order to prepare young people for future work as religion teachers.

$17 \quad$ A. Nossol, Homilia ekumeniczna, in: ibid, pg. 247.

18 For example, the follow events took place: the international conference Religious Relations in Cieszyn Silesia in October 1996; the academic session An Opportunity or a Threat to Polish Frontiers in 1998; the academic session Reconcile: A Pastoral and Socio-cultural Dimension of Ecumenism in Cieszyn Silesia in 2000; the academic session Into the Third Millenium with the Holy Spirit in 2001; and Sects and New Religious Movements - An Ecumenical Study in 2003. Cf. Ibid, p. 163-172. 


\section{Practical Sociocultural Ecumenism}

Just as faith without deeds is dead, authentic ecumenism cannot exist without reciprocal actions. The Decree on Ecumenism Unitatis Redintegratio emphasizes that not only Christians but "all people" (12) must cooperate with each other.

One of the main foci of ecumenical activity (and also the basis of practical activity) are married couples who belong to two different denominations (i.e., mixed couples). Churches should provide special care for these marriages. The following rules are vital in the ecumenical pastoral work of families: encouraging the faithful to pray for the unity of Christians and to participate in common services and other parish activities; to become more knowledgeable about their respective Churches; to educate their children about the spiritual richness of both Churches by having them participate in celebrations, services, and common gatherings at them, even if the children are affiliated with one Church in particular. There are areas in Cieszyn Silesia where Catholic priests and Protestant ministers visit interfaith families together. First the ministers pray together, and then they discuss different subjects with the family. Understood in this way, ecumenical ministry can be a way to strengthen the love between the spouses, and this love can serve as an example of ecumenical love and a sign of unity for the divided Church. Ministries to mixed couples that are well-run can be very fruitful, and these couples can potentially become excellent examples of the effectiveness of ecumenical activities.

The Churches in Cieszyn Silesia drew particular attention during the martial law in Poland (December 13, 1981 - July 22, 1983). During this period, the different charities of all of the Christian denominations worked together, and the help that they provided each other sincerely fulfilled the commandment of love. In those days it was not important to which denomination one belongs, but the fact that each person is a human being.

Since 1999, Cieszyn Silesia has hosted the Religious Creativity Festival "Pasalite Deo" under the auspices of the Ordinary Bishop of the Diocese of Bielsko-Żywiec, the Head of the Diocese of Cieszyn's Evangelical Church of the Augsburg Confession, the Ordinary of the Diocese of Eódź-Poznań's Autocephalous Orthodox Church, and the Bishop of the Evangelical-Reformed Church in Poland. This cultural and musical event has an ecumenical character, and the concerts take place in Catholic and Evangelical churches.

Within the Cieszyn region of Silesia there are kindergartens, primary schools, and secondary schools run by the Catholic and Evangelical 
Churches, and students of both denominations attend these schools. Recently, research has found that these students have a positive attitude towards each other, and their teachers are kind and unprejudiced.

In addition, no one in this region is surprised when a Catholic church rents one of its buildings to Protestants who lacks the same kind of facilities at their own church. When necessary, Protestants, likewise, allow Catholics to use their church as they did in, for example, Międzyrzecze where a fire destroyed the Catholic church on January 25-26, 1993.

\section{Conclusion}

John Paul II appreciated the importance of the ecumenical movement in Cieszyn Silesia. During his visit to Skoczów on May 22, 1995, he delivered a speech addressed to the Lutheran and Catholic clergymen and congregations, during which he said:

The region where we are right now, I mean [...] Cieszyn Silesia, is known in Poland as a place of particular ecumenical witness. For ages it has been a place of harmonious coexistence between members of the Catholic Church and the Evangelical Church as well as intensive ecumenical dialogue. This dialogue is carried out with the deep conviction that closely joins us - that we are joined by a common faith in Christ and by our common Fatherland. On the occasion of this meeting, I would like to express my personal satisfaction with and gratitude for the fact that this ecumenical dialogue develops and becomes deeper, and that it is reflected in many concrete forms of cooperation: both on the diocesan and parish levels. ${ }^{19}$

When Christians join their voices on issues of morality, culture, and upbringing, they bring society together and give its members a sense of unity in the pursuit of their common goal to build a civilization of love, peace, and justice. In these activities, in which more and more young people are involved, Jesus words "That they may all be one" (J 17:21) are fulfilled. When analyzing how the Decree on Ecumenism Unitatis Redintegration was received among the multi-dimensional society of Cieszyn Silesia, the most eminent Polish ecumenist Fr. Prof. Wacław Hryniewicz's words come to mind: "An authentic reception can be achieved only when the partners differ from each other, because diversity enables a true relationship between giving and taking." 20

19 John Paul II, "Przemówienie wygłoszone w czasie spotkania z wiernymi w kościele ewangelicko-augsburskim w Skoczowie," in: Drogowskazy dla Polaków Ojca Świętego Jana Pawła II, Cracow 1999, vol. 3, pg. 273.

W. Hryniewicz, Hermeneutyka w dialogu, Opole 1998, pg. 158. 
When the wise of "today" look back on "yesterday" in order to build a better "tomorrow" as they do in Cieszyn Silesia, they serve as an example of how to act for Churches and Christian communities.

\section{Bibliography:}

1. Biermann, G. Geschichte des Herzogthums Teschen, Teschen 1894.

2. Budniak, J. Ekumenizm jutra na przyktadzie Ślaska Cieszynskiego, Katowice 2002.

3. Budniak, J. "Ekumenizm na Śląsku Cieszynskim na przetomie wieków." In: Pojednajcie się.... Edited by J. Budniak and H. Rusek, Cieszyn 2000, pgs. 69-75.

4. Budniak, J. "Wkład społeczności lokalnej w proces pojednania chrześcijan." In: Człowiek dialogu. Edited by Z. Glaeser, Opole 2012, pgs. 611-624.

5. Second Vatican Council. Decree on Ecumenism Unitatis Redintegratio. https://w2.vatican.va/content/john-paul-ii/en/speeches/2003/april/documents/hf_jp-ii_spe_20030414_univ-2003.html (accessed 10.30.2019).

6. Heinrich, A. Versuch über die Geschichte des Herzogthums Teschen von den ältesten bis auf gegenwärtige Zeiten, Teschen 1818.

7. Hryniewicz ,W. Hermeneutyka $w$ dialogu, Opole 1998.

8. John Paul II. Encyclical Ut unum sint, Vatican City 1995.

9. John Paul II. "Address to the Young People Taking Part in the International Meeting UNIV 2003," April 14, 2003, https://w2.vatican.va/content/ Ecumenism john-paul-ii/en/speeches/2003/april/documents/hf_jp-ii_spe_20030414 univ-2003.html (accessed 10.30.2019).

10. John Paul II, "Przemówienie wygłoszone w czasie spotkania z wiernymi w kościele ewangelicko-augsburskim w Skoczowie," in: Drogowskazy dla Polaków Ojca Świętego Jana Pawła II, Vol. 3, Cracow 1999.

11. Nossol, A. "Homilia ekumeniczna." In: Drogowskazy dla Polaków Ojca Świętego Jana Pawta II, Vol. 3, Cracow 1999, pgs. 246-248.

12. "Ordinary Bishop of Bielsko-Żywiec diocese Tadeusz Rakoczy's speech to the participants of the International Ecumenical Congress." In: Budniak J., XXVIII Międzynarodowy Kongres Ekumeniczny w Cieszynie. Ora et labora, Cieszyn-Bytom 1996.

13. Panic, I. "Ziemia Cieszynska w czasach piastowskich (X-XVI wiek)." In: Ślask Cieszynski. Zarys dziejów, Cieszyn 1998, pgs. 25-43.

14. Popiołek, F. Dzieje Ślaska austriackiego z ilustracjami, Cieszyn 1913.

15. Rakoczy, T. "Słowo wygłoszone podczas nabożeństwa ekumenicznego w kościele pw. Najświętszego Serca Pana Jezusa w Bielsku-Białej, 25 marca 2000 roku." In: Pojednajcie się... Edited by J. Budniak and H. Rusek, Cieszyn 2000, pgs. 243-245.

16. Schmemann, A. Velkij post, Pariž 1981.

17. Slama, F. Dějiny Těšinska, Prag, 1889, passim; G. Biermann, Geschichte des Herzogthums Teschen, Teschen 1894. 